\title{
I Sing, Therefore I am-The Political Representation of Taiwanese K-pop Urban Fans at K-pop KTV (Karaoke)*
}

\author{
Haerang $\mathrm{NOH}$ \\ National Chengchi University, Taipei, Taiwan
}

\begin{abstract}
The Korean popular cultural waves have been spread into East Asia for more than a decade. In late of 2000, for most of the perspectives about Korean waves had been moved on the 3rd stage of the K-pop industrial structure, K-pop idol stars as contents of Korean popular music have turned the pivotal contents in East Asia and West countries. This research examined how Taiwanese K-pop consumers are identified as the K-pop enthusiast legitimizing and what they represent the "prosumer" of Korean popular music. Moreover, the practice of K-pop is getting turn consumer in Korean song karaoke (KTV) in Taipei city. What sort of cultural form emerges the political representation in the cultural space, K-pop KTV in Taipei. Through how Taiwanese K-pop followers diverse K-pop music for singing K-pop in KTV, it could more elaborate the meaning of contents the culture form of space between production and consumption of the cultural mediation.
\end{abstract}

Keywords: K-pop, cultural diversion, Karaoke space, practice, Marxist feminism

\section{Karaoke of the K-pop, by the K-pop, for the K-pop in Taipei}

K-pop fevers are going to reach to all around Asia countries and over to the different cultural areas, South American and West countries during last ten years. In the background of acceptation of the content, K-pop music, K-pop entertainment companies are utilizing by internet sources as an alternative marketing method. As the first of SM town live concert in Paris at June 2011, through attended around 14,000 ticket buyers observed K-pop fans were separated in Europe ${ }^{1}$. Schmidt, the CEO of Google company, announced they would arrange the K-pop You tube official channel ${ }^{2}$ on the You tube from December 2011 when he visited Republic of Korea at November in the same year officially. In the background of the partnership between Google and K-pop contents, Google intend to reflect that the K-pop contents had been engaging the recognizable contents on YouTube around 2010 year. For instance, there were already 4 million viewers clicked for TVXQ (东方神起)'s each official music videos, and another 3.4 million viewers for Girls Generation's, and 2.6 million viewers for Wonder Girls' in short period, etc.. K-pop contents had been built more a specific brand, as the distinguished pop music "K-pop" on the internet, as emerged the millions of music video viewers for each K-pop by over 20 Korean Idol stars during the same term.

The globalized K-pop industry and K-pop fandom emerged from the popular culture in Asia and the contents spared out to West countries through the internet and digital technology devices. According to the

\footnotetext{
${ }^{*}$ KTV means the Karaoke and the prefix of Karaoke Television in Taiwan as well. For more explain, see Chapter 2 in this paper. Haerang NOH, Ph.D., Department of Journalism, National Chengchi University.

1 Source: [SM Town live in Paris 2011], Retrieved from http://www.youtube.com/watch?v=Wq6JCmXNO34

2 Source: Retrieved from https://www.youtube.com/user/kpop
} 
research about the Korean waves by KOFIC ${ }^{3}$, the Korean Waves underwent to the third stage that extended to other cultural territories and contents (see Table 1). As refer to the front, K-pop and Korean idol stars take lead the latest stage of Korean waves, Korean popular songs and artists were the core contents for the present Korean wave stage. For the raising of K-pop products and the success of K-pop market, however, there are few treating the issue of K-pop audiences' practice with K-pop music in everyday life. Otherwise, Taiwanese K-pop followers have been taking an active part in making the cultural material circle between consumption and reproduction as the cultural laborers. Furthermore, they had been building up the consumers of sovereignty as well in the last ten years.

Table1

The Stage Flow of Korean Waves

\begin{tabular}{|l|l|l|l|}
\hline & The first Stage & The Second Stage & The Third Stage \\
\hline Key words & Birth of Korean Wave & Intension of Korean Wave & Diversity of Korean Wave \\
\hline Period & 1997 till 2000 & The mid of 2000s & After later 2000s \\
\hline Main Genres & Soap operas, K-pops & $\begin{array}{l}\text { Soap operas, K-pops, } \\
\text { Films, Online games }\end{array}$ & $\begin{array}{l}\text { Soap operas, K-pops, Films, Online } \\
\text { games, Cartoon, Korean, Foods }\end{array}$ \\
\hline $\begin{array}{l}\text { Boundary of } \\
\text { Influence }\end{array}$ & China, Taiwan, Vietnam & $\begin{array}{l}\text { China, Taiwan, Vietnam, Japan and } \\
\text { East Asia }\end{array}$ & $\begin{array}{l}\text { China, Taiwan, Vietnam, Japan and } \\
\text { East Asia, Mid-Asia, USA, Africa, } \\
\text { EU }\end{array}$ \\
\hline $\begin{array}{l}\text { Main } \\
\text { Contents }\end{array}$ & $\begin{array}{l}\text { Drama: What love it is } \\
\text { Idol group: HOT }\end{array}$ & $\begin{array}{l}\text { Drama: Winter sonata (冬季恋歌), A } \\
\text { Jewel in the Palace (大长今) }\end{array}$ & $\begin{array}{l}\text { K-Pop and Idol stars, } \\
\text { Online games }\end{array}$ \\
\hline
\end{tabular}

(Source: Adapted from Go, 2011, p. 50)

This research relies on extensive fieldwork experience and both as the observer for the K-pop consumer's using and representation meaning behind in leisure activities with K-pops. Karaoke (KTV), therefore, is one of the patterns for music consumption and a sort of leisure for representation as K-pop consumers. In the same perspective, K-pop Karaoke in Taipei is offering the meaning of cultural space and mediating the constituents of Taiwanese K-pop followers. In other words, under the third stage of K-pop flow, what values involved to Taiwanese audience representation in K-pop karaoke reflect to the users of internal nature for the cultural distinction and the tension of cultural space, karaoke for Korean language lyrics songs only.

\section{The Present Study}

Historically, the first karaoke bars known in Taipei were established sometime in the second half of the 1970s under the overpass along the Hsin Sheng North Road (新生北路) in Taipei city. According to the composer Lin Erh, who was a regular customer of one of those shabby bars in the dusty and noisy neighborhood, there was no Chinese rendering of "karaoke" at that time, these karaoke bars had a sign that said “Singing”(ko chang 歌唱) in Chinese ideograms or “Karaoke” in Japanese writing. Although the karaoke box became popular in the late 1980s, it prototype can be traced back even before its importation from Japan. It was not derived from karaoke bars but from a small room for viewing music video usually called M-TV ("M" stands for Movie). The M-TV was launched around 1984 but soon after was used for video movies too, since it cost less than the cinema and allowed the clients to see the movies they rented at video shops. However, according to the request of the Uruguay Round Table, General Agreement on Tariffs and Trade (GATT) accused to Taiwan government for the copyright protection and the problem of video piracy, the most of M-TV shops

\footnotetext{
${ }^{3}$ KOFIC stands for "Korean Films Council” (Retrieved from http://www.koreanfilm.or.kr/jsp/index.jsp).
} 
were defined as illegal and were forced to close by Taiwan government. This devastating act gave birth to KTV (“K” stands for karaoke) (Otake \& Hosokawa, 1998, pp. 179-181).

As short histories of KTV in Taiwan, KTV had been taken for grant a leisure activity with popular music to Taiwanese. Till 2010 years, KTV had been a sort of the populist of leisure activity for Taipei citizen's society and became a part of everyday life for representing one's preference popular songs that they want to sing in a singing room with others. KTV leisure is not for individual activity, but as a group activity at the concurrent time and real same place. Here is an observation about the behaviors in karaoke space, Casey quoted Kimindo Kusaka's comment, and he mentioned karaoke was a part of the "culture of form”. In any country, more than half of the citizens live a life of following orders from above (Lum, 1998, p. 172).

In same words, someone goes to the karaoke with some particular category person, it is not only the audiences' taste in popular music as a method of economic market analysis but also involved the meaning of social agency's behavior within a case of leisure activity.

\section{Leisure of Sociology}

In studies of urban leisure life, the leisure contents and popular categories concerned with social and economic factors. Roberts (2010) researched the issue of relation between gender and leisure life. He argued that during the 1980s this replaced work as the leading issue in the sociology of leisure. Second-wave feminism forced gender up the research agenda. Feminist's initial complaints were that leisure research had neglected gender in general and women's leisure in particular. These criticisms were immediately accepted, and it is now 20 years since it was possible to complain that gender or women's leisure was neglected (Roberts, 2010, p. 5). This new issue has been taken the existing perspective as Roberts mentioned. In addition, the main argument in this study is emerged the relation between gender and leisure life as well.

Table 2

Leisure Activity in 2002

\begin{tabular}{|c|c|c|c|c|c|c|c|c|c|c|}
\hline & $\begin{array}{l}\text { Newspaper / } \\
\text { Magazine }\end{array}$ & $\mathrm{TV}$ & KTV(Karaoke) & $\begin{array}{l}\text { Movie/ } \\
\text { Music }\end{array}$ & Internet & Shopping & Sports & Talk & Volunteer & Others \\
\hline Female & 47.38 & 21.29 & 9.22 & 62.52 & 46.66 & 42.18 & 13.78 & 22.88 & 6.03 & 8.68 \\
\hline Male & 36.39 & 24.75 & 9.40 & 56.74 & 64.92 & 17.35 & 41.15 & 19.15 & 4.64 & 5.58 \\
\hline Ave. & 41.56 & 23.12 & 9.32 & 59.45 & 56.33 & 29.03 & 28.27 & 20.91 & 5.29 & 7.19 \\
\hline
\end{tabular}

(Source: Adapted from QIU, 2010)

Karaoke activity is actually became a choice for Taipei citizen's leisure life, the karaoke room is a distinct leisure activity to Taipei citizen (see Table 2). For understanding the meaning of karaoke within everyday life, we might consider what kind of social factors affected to karaoke leisure. Previously, we need to fix out the term of leisure for this research in sociological perspective. It is likely that any societal role will always depend on the type of leisure and the other roles of the actors or consumers. Leisure may play a strong role in identity stabilization during a certain life stage such as youth, and then recede in importance (Roberts, 2010, p. 8). In addition, just as in the 1960s, the sociology of leisure needed to draw on broader sociological theories about changes in 21st-century societies. For example:

The kinds of work-life balance and imbalances experienced by different socio-demographic groups in different countries; The implications for patterns of stratification of changes in the distribution and types of economics, social and cultural assets; The long-term implications of past and current changes in leisure socialization during childhood, youth and 
young adulthood; The consequences for leisure behavior and social identities of the growth of commercial consumer industries and the spread of the associated consumer cultures; The implication of governments looking increasingly towards the leisure industries to promote economic growth, or to prevent stagnation or degeneration. (Roberts, 2010, p. 9)

As Roberts (2010) mentioned, the leisure activities connect with economics, social and cultural value and identity. As well as the nature of leisure activity, it focuses on the popular music with everyday urban life in this research. What kind of methods are popular music audiences using the popular music products? Except to listen to popular music, how do they elaborate their identity through the genre and style of popular music that they prefer? Hence, part of a popular musician's learning occurs in groups where musicians can watch and imitate other experience players. Group learning gives musicians a chance to "copy and exchange ideas, knowledge and techniques, and learn to play together” (Green, 2002, p. 97).

In another inquiry issue, both of biology and genetics are the significant perception for KTV behavior. However, there are several limitations need to be noticed. This study is only a narrow research and future study needs to extend to several areas, for example, Chick (2008) mentions that anthropology of leisure would explore the innate character of adjustment during doing leisure activity like art (includes: the graphic arts, music, dance, drama, stage play, philology, and literature), entertainment, games, sports, joking, hobbies, handicrafts, festivals, beauty pageants, religious rites, and media. Moreover, the ethnography of leisure, cross-cultural validity of the concept of leisure, leisure and the evolution of culture, and cross-cultural comparative studies of leisure (Chick, 2008) are not only investigating both of communicate-culture and KTV behavior are rational and habitual-reflective behavior, but also proving Chick's (2008) belief that communicate-culture is the way that human has done for survival, and leisure behavior, an intuitional-reflective behavior, is the way to adapt culture.

In short, the leisure activity involved the social role for not only presenting out social agencies' life style, but also establishing a community to reinforce one's identity. For more approach to the main topic, we need to discuss KTV as a leisure activity separately, also further more to understand the cultural role of KTV.

\section{KTV, Behind of a Sort of Leisure Activity}

The study between karaoke culture and the user behavior focuses on the popular culture by the perspective of media sociology or social psychology. In the point of view to leisure meaning in social, within its own discipline the sociology of leisure has always faced rival claims on its field. Initially the main challenge was from cultural studies, especially the genre that examined popular cultures. Media sociology has always positioned itself outside the sociology which has always positioned itself outside the sociology of leisure, and likewise the sociology of the arts. Youth researchers have been more likely to investigate youth cultures than youth leisure (Roberts, 2010, p. 2).

In social psychology, meanwhile, it predicts the intension and action under the relationship of the individual and external social behavior. One of the perspective is the theory of reasoned action (TRA), as mentioned by Fishbein and Ajzen, that insists one’s belief will influence his/her taste attitude on a circumstance, and the social-pressure be evoked by self-regulation of social agent. Moreover, attitude and self-regulation will affect his/her intention toward this issue and this intention is the key for him/her performing the behavior. On another conception is the theory of planned behavior (TPB), which believes individual's behavior is decided by individual's intention. However, except internal factor, attitude, and external social pressure, self-regulation, TPB is mentioned that behavior also should be measured by the time and opportunity factors, perceived 
behavioral control (Ajzen, 1985). The consumption behavior in karaoke, in other words, which is a part of the leisure behavior came out the user's intention and it is the cause of performing in karaoke.

Criss (2008) describes the natural learning process as involving five steps beginning with observing to get a goal, then forming a mental imagery, imitating, trial and error, and finally practicing. Motivation was mentioned as an important factor that sparked off learning in students. Amongst the five steps, imitation is described as a "natural ability we have when we are born" (Criss, 2008, p. 44) and through imitation, students can "feel and experience" and thus learn better (FANG, 2009, p. 5). In the same context, Lilliestam (1996) as cited in Folkestad (2006) describes the process of learning as consisting of the three major steps of listening, practicing, and performing. This performance aspect of music learning is emphasized by Drinker (1967) who advocates active participation in the performance of music by amateurs, in addition to intelligent listening which is described as a prerequisite to musical understanding. Small (1998) elaborates that engaging in a musical performance is an affirmation to the world of the performer's identity and therefore needs to be taken seriously (FANG, 2009, p. 6).

The identification of patriarchy as a "system of structures and institutions created by men is in order to sustain and recreate male power and female subordination", and the coalescence between theory and practice was fundamental to the political perspectives of radical feminism. In particular, there was an identification of the need for collective action and responsibility, and an acknowledgement that women's experience, whether heterosexual or lesbian, was rooted in the cultural and social circumstance of their lives. However, the recognition of women's oppression as universal, crossing race, class, and other delineating boundaries such as age and physical ability, carried with it the implication that perfect equality is impossible and that matriarchy and separatism might well be the only viable solutions. The identification of "sisterhood" as a cohesive revolutionary force for developing self-identity in relation to other women, for "putting women first", led to a defense of separatism engaging in women only groups, engaging in political and social action with other women (Whitley, 2000, pp. 45-46).

In summary, the implication of the commercial singing room consumer's behavior and their choice for leisure time could be examined under the theory of social psychology, as TRA (the theory of reasoned action) or TPB(the theory of planned behavior). In other words, through the popular music practical and performance by self-identity, the performer in KTV is not only for simple personal entertainment, but he/she reinforces identification during sharing the singing song at the same time and space. In other words, what motivation and intention make the Taiwanese K-pop audiences lead to K-pop KTV? Meanwhile, If they more share the same category music or the distinguished genre and language of lyrics popular music, there could be formed what shape of political meaning? In this research, the author focused on K-pop KTV in Taipei and the KTV customers practice for approaching his inquiry issue.

\section{Evidences}

In research, the author followed two inquiry methods: data analysis and in-depth interview. For more getting approach to K-pop KTV consumers' behavior intention, they need to treat the K-pop materials they shared and referred on online. In the other method, the author had contacted nine Taiwanese female participants for this research and they were separated in two groups ${ }^{4}$, group A (see Appendix, Table 4-1) organized by four

\footnotetext{
${ }^{4}$ See the appendix "Table 4-1 and 5-1" in this paper.
} 
females (A1 A4) and the other five all female members (B1 B5) for group B (see Appendix, Table 4-1), organized under the natural causality progress by every single oneself.

\section{Secondary Data}

The author gathered data about the main K-pop Karaoke, “EST(伊斯特) KTV” in Taipei city (see Appendix, Table 4-2). Data sources relied on EST KTV main homepage and internet blogs that concerned with news and issues about K-pop recently or historically. The full name of EST KTV is "EST Japanese and Korean popular song center” and they are managing three chain stores in Taipei city.

Table 3

The Cost List of EST KTV (Unit: TWD)

\begin{tabular}{lllll}
\hline Time & Monday Thursday & Friday & Saturday & Sunday \\
\hline 10:00 11:29(07:00 11:29) & $230(25)^{*}$ & $230(25)$ & $300(30)$ & $300(30)$ \\
11:30 15:59 & $270(30)$ & $270(30)$ & $300(35)$ & $300(35)$ \\
16:00 22:59 & $300(30)$ & $350(35)$ & $350(35)$ & $350(30)$ \\
23:00 02:00(23:00 07:00) & $280(30)$ & $380(35)$ & $380(35)$ & (Need Reservation) \\
\hline
\end{tabular}

(Source: EST KTV homepage) * Charge tips: 3hrs per person and “(Num)” is for the extra charge for every 30 minutes a person.

They manage 7 days a week and the cost system followed the graded charge like the normal KTV (Cashbox Party 钱柜 KTV, Holyday 好乐迪 KTV) in Taipei city (see Table 3). The cost level of the EST singing room is higher than the other singing room's chains in Taipei as participant $\mathrm{A} 1^{5}$ said, EST is a little bit expensive for the ordinary customers. They are issuing the membership card for maintaining regular customers. K-pop KTV consumers only must follow the original lyrics in the KTV. Basically, EST KTV equipped the device for several different languages songs including Korean popular music and Chinese, Japanese songs as well. But group A and B members went to EST KTV in order to sing and listen to K-pop with each other in the major object. There could induce to two kinds of K-pop performance types: One type is for the non-Korean language learners and another is for Korean learners. To the former case, they rely on the assonant of original lyrics, and they use to imitate Korean pronunciation by re-formation of Chinese or Taiwanese language, as called "Kong-er (空耳)" in Chinese. As a sound symbol, the non-Korean learners practice the pronunciation of K-pop lyrics with the kong-er. According to one of several introducing “Kong-er (空耳)” blogs on internet sites, the title mentioned to "You sing with original version music video, make you feel better (in Chinese “原版 MTV越唱越有FU!!””. Even if the Korean incapable audiences are willing to get closer to sing K-pops, they are attending to feel K-pop as singing by their selves.

Also the imitated Chinese lyrics version by Girls Generation “Run Devil Run” on Youtube responded:

试试看.(Try this.) 第一 因为不会韩文. (Can’t speak Korean..)

第二 对着发音边听边唱依然不会唱(汗) (I can sing song follow the music, but cannot sing by myself (sweat))

我想我有韩文障碍吧 $\mathrm{T} \wedge \mathrm{T}$ (I think I have a learning disability for Korean $\mathrm{T} \wedge \mathrm{T}$ )

话说这版本名字好像太长了==”拍谢 (This title of version is too long. = =” Sorry)

而且因为是注解. 好像读的速度很慢 (And I attached by annotating, so it made slow down to read out) p.s. 空耳就是听谐音来记歌词用的唷

\footnotetext{
${ }^{5}$ See the appendix "Table $4-1$ " in this paper.
} 
(p.s. Kong-Er means imitated the original lyrics pronunciation just rely on listening and handing out) ${ }^{6}$

As we saw some subsistence, the non-Korean learners are exchanging information each other for singing in original Korean lyrics. The reason is that they have a desire to perform K-pop music that they have seen or listened expediently. Furthermore, they want to confirm that he/she is one of the K-pop fans of a genre and style of K-pop artist. The rate of non-Korean users and Korean learners is out of the range for this issue, and not fixed the term of Korean learner but there set up two Korean learners groups who are the customers for EST KTV in Taipei city.

\section{Conversations With Two Groups}

In this research, the author ordered to two of participants (A1 and B1) each of groups to recording sounds and every single conversation during the singing activity at the KTV rooms. From organizing group member till each group going to KTV, all processing depends on participant's self will, not installed by researcher artificially. And the author got three interviewees from two groups’ participants: A1, B1, and B2.

First of all, the author asked the motivation and the distinguished to go to K-pop KTV. Participant A1 referred to the question as said:

I'll go if I have no choice. Not all of my friends like Korean songs or know how to sing Korean songs. I think KTV is depends on individuals like and dislike. Ms. Cheng (Participant A2) actually don't like go to K-pop KTV.... (personal communication, May 19, 2012)

Participant A1 attached to: “...Because they listen to Korean songs, they are willing to go to EST”. She said she is not a hard K-pop follower, she told me:

It happened once when my Korean friends came to Taiwan. We had no idea about where should we go after dinner, so we went to Korean KTV. Except once that my Korean friends came to Taiwan, we always go there without male friend. The only reason is all my male friends don't know Korean songs much. (personal communication, May 19, 2012)

Also, particularly, they organized members who have the background of Korean language learning and willing to sing K-pop each other. In other words, when they arrange to go to karaoke for leisure activity, they must consider the members character.

The author asked to interviewee A1 about the genre that she likes and practice pattern before coming to K-pop KTV. She answered: “I won’t do any preparation just for going to KTV. But I do like to sing particular singers' songs” (personal communication, May 19, 2012). In the conversation of Group A, the participants talked about song and music video also. Participant B1 responded to same question:

Hmm, My song list? Well, I often take watch some K-pop program, for example "Music Bank"7 or "Hit songs”, in Internet. I want to listen new songs from the local program at the same time. (personal communication, May 19, 2012)

“My favorite program is 'I'm a singer', broadcast on MBC. Of course I'm watching on internet. I really like to watch the program. I could encounter old K-pop by the cover song version” (personal communication, June 30, 2012) participant B2 said. Under the wireless and mobile individual media atmosphere, Taiwanese audiences rely on internet to connect to Korean TV program and gather new K-pop at real time. Participant B1 and B2 mentioned: "We just got EST KTV today but there was no updated new songs in June issued yet.

${ }^{6}$ The imitated Chinese lyrics version by SNSD “Run Devil Run” (少女时代 SNSD Run Devil Run 中文空耳 好多人好 多食物 背他到腿软版) (Retrieved from http://www.youtube.com/watch?v=ACmznc4IJFA\&feature=related).

${ }^{7}$ A kind of K-pop entertainment show program produced by KBS(Korean Broadcast System).

${ }^{8}$ A kind of K-pop entertainment show program produced by SBS(Seoul Broadcast System). 
Maybe we need to wait a couple weeks” (personal communication, June 30, 2012). Digitalized media device offers the marital that Taiwanese K-pop audiences need for popular cultural autonomy and motivation to identify.

In another analysis of two groups' song list (see Appendix, Table 4-2, Table 5-2), two different groups participated in this research for sample, Group A recorded 29 songs (Recorder missed 40 miniutes in front of beginning) and Group B recorded 47 songs in same branch room of EST KTV and at different date. We can figure out several common points from two recordings. About song list, all seven songs duplicated (see Table 4). In this observation experiment, the author realized five of seven duplicated songs are concerned with Korean drama. The five Original Sound Tracks (OSTs) are not new songs but participants of two groups selected. In another common point, all 76 songs are sung by nine participants, 25 songs are listed on Korean dramas and films OST.

Table 4

Duplicated Songs List of Group A and Group B

\begin{tabular}{|c|c|c|c|c|}
\hline & Song Title & Album (Year) & Artist & Memo \\
\hline 1 & $\begin{array}{l}\text { Love, Oh love } \\
\text { (사랑, 사랑아) }\end{array}$ & $\begin{array}{l}\text { Love Delight } \\
\text { (August 2011) }\end{array}$ & Davichi & $\begin{array}{l}\text { Duo female R\&B singer (Member: Kang Minkyeong, Lee } \\
\text { Haeri) }\end{array}$ \\
\hline $2 *$ & $\begin{array}{l}\text { I love you } \\
\text { (사랑해요) }\end{array}$ & $\begin{array}{l}\text { Athena OST } \\
\text { (December 2010) }\end{array}$ & $\begin{array}{l}\text { Taeyeon } \\
\text { (太妍) }\end{array}$ & $\begin{array}{l}\text { Singer: Girl's Generation member, leader vocal (SM Ent.) } \\
\text { SBS drama “Athena” OST (Period :13 December 2010 21 } \\
\text { February 2011) }\end{array}$ \\
\hline 3 & $\begin{array}{l}\text { You and I } \\
\text { (너랑 나) }\end{array}$ & $\begin{array}{l}\text { Last Fantasy } \\
\text { (November 2011) }\end{array}$ & IU & Singer and Actress (with LOEN Ent.) \\
\hline $4^{*}$ & $\begin{array}{l}\text { I have a lover } \\
\text { (애인 있어요) }\end{array}$ & $\begin{array}{l}\text { Ma Non Tanto } \\
\text { (November 2005) }\end{array}$ & Lee, Eunmi & $\begin{array}{l}\text { Singer (with Neobiz Ent.) } \\
\text { MBC “Last scandal” OST (8March2008 27April 2008) }\end{array}$ \\
\hline $5 *$ & $\begin{array}{l}\text { Loving you, today } \\
\text { (오늘도 사랑해) }\end{array}$ & $\begin{array}{l}\text { The Princess’s Man } \\
\text { OST (July 2011) }\end{array}$ & $\begin{array}{l}\text { Baek Ji-young } \\
\text { (白知英) }\end{array}$ & $\begin{array}{l}\text { Singer (with WS Ent.) } \\
\text { KBS “The Princess’s Man (公主的男人)” OST }\end{array}$ \\
\hline $6^{*}$ & $\begin{array}{l}\text { Do you hear me? } \\
\text { (들리나요) }\end{array}$ & $\begin{array}{l}\text { Beethoven Virus } \\
\text { OST (September } \\
\text { 2008) }\end{array}$ & $\begin{array}{l}\text { Taeyeon } \\
\text { (太妍) }\end{array}$ & $\begin{array}{l}\text { Singer: Girl’s Generation member, leader vocal } \\
\text { MBC “Beethoven Virus (贝多芬病毒)” OST }\end{array}$ \\
\hline 7* & White love story & $\begin{array}{l}\text { Coffee prince OST } \\
\text { (July 2007) }\end{array}$ & Lin & $\begin{array}{l}\text { Singer : A member of group “As One” (Looterson Ent.) } \\
\text { MBC “Coffee prince (咖啡王子一号)” OST }\end{array}$ \\
\hline
\end{tabular}

* Source: It marked for Korean drama OST (No.2 and No.4 till No.7) (Source: Figured out in this research)

Through K-pop performance, they want to show up a kind of positioning about the same category, K-pop music. Participant A1 said,

Well... not really, I will ask the name and listen to it if I like it. But I won't sing that songs when we go to KTV next time. I believe that everyone has his/her own songs and wants to sing it alone (personal communication, June 30, 2012).

Participant B1 responded to same question and said,

It's not difficult to recognize to the different class at the KTV room. For example, I like to watch Korean Soap opera (drama). One of reason is to enjoy the OST. I'm not a enthusiast for K-pop practice so just depend on listening. Of course, I’m listen new K-pop idol stars' song, but not much like singing the songs. (personal communication, June 30, 2012)

Another Participant (B2) agreed to this statement, and said:

I like listening love song so I love to watch Korean drama too. Actually, some of idol group songs too fast to me. Not easy follow the lyrics. But 1 can sing some lyrics, like English words or reversed single lyrics partly. It's so fun. (personal communication, June 30, 2012)

Actually, there is connection of K-pop singer and drama OST. The broadcasted of most drama is not by 
TV monitors but through PC monitors by internet or mobile devices. In same words, Korean drama is one of the K-pop mediation till this third Korean wave stage. K-pop still concerns with K-pop idol stars participated dramas and films OST.

\section{Discussion of Result and Conclusion}

KTV is a very popular leisure activity in Asia for entertainment and social events. Karaoke is the major installation inside the tiny partition. Drink and food are served. Dimming lights makes people feel more relaxed and comfortable. Lyrics lead the guests singing and dancing along with music video in stereo. People might know or might not know each other very well. Through certain connection though, they come together and try to enjoying themselves. The behavior intention of individual attends to the use behavior in KTV. Taiwanese K-pop KTV audience have autonomy to select K-pop genre that she likes and will to share their interest about topics of Korean popular culture contents. Korean wave is chained with each genres, especially K-pop is positioned as the core mediation of the Korean wave contents, and the role of K-pop KTV in Taipei would be the space for practicing and communication by the K-pop fans in Taiwan.

\section{Limitations}

The findings are based on two groups' point of views as the observing of this study is all nine females who have the background of learning Korean. They usually attend K-pop KTV activity with members who have Korean capability. The author tried to approach the meaning of K-pop KTV space and what K-pop KTV customers consume. However, it did not reveal clearly the distinction of K-pop KTV and ordinary Taiwanese KTV through this conversation with several participants. As participant A1 argued:

Actually, I don't feel any difference about atmosphere between Taiwanese pop KTV and EST KTV. The only difference between Taiwanese KTV and Korean KTV in Taiwan is F \& B (Food and Beverage) regulation (personal communication, May 19, 2012).

The value of K-pop KTV is constructed in all of their single conversations and behaviors from before get in the KTV box till dismiss. But the author did not get more evidences for digging research problem, he stayed to record and analysis sentences.

The author did not control any limitation for this study, in result, group A drank some alcohol before getting in KTV room but group B was not. Two group’s recordings have time gap, almost one month, which means it could affect the motivation to go to K-pop KTV for singing.

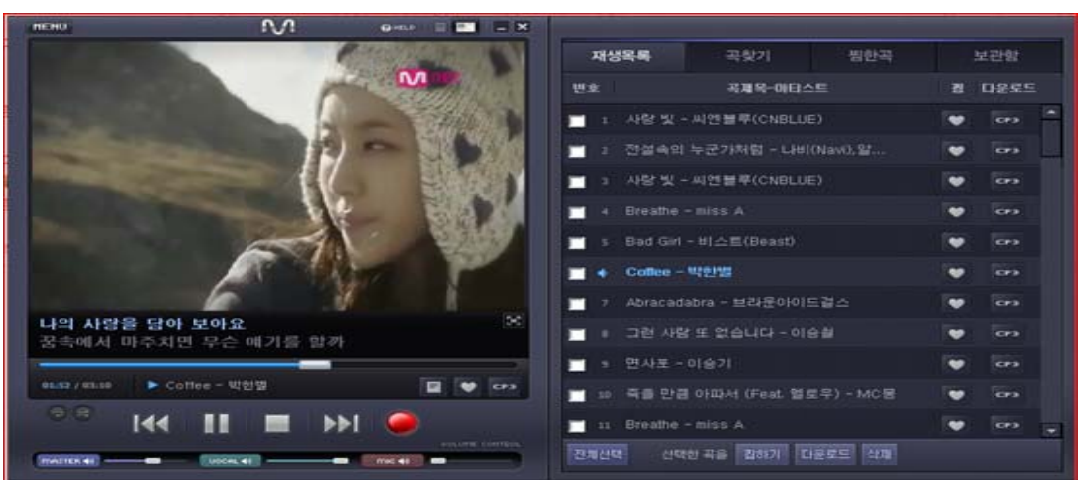

Figure 1. The online Karaoke songs list. Source: Internet K-pop KTV! For Free!! 好玩的韩国线上KTV!!!免钱也能 唱!! Retrieved from http://sss501.pixnet.net/blog/post/32880352-好玩的韩国线上ktv!!!免钱也能唱!! 
In other perspective, the issue of media technology extended to E-Karaoke. The online Karaoke songs list (see Figure 1), K-pop audiences already used the homepage service. In addition, the perspective of Marxist feminism, the main K-pop KTV customer is account for female that is absolute majority. The author believes that there needs to elaborate about what kind of social agency involved with K-pop KTV and how to reproduce popular culture. Furthermore, the author is looking forward to clearing about the fandom culture of Korean waves.

\section{References}

Ajzen, I. (1985). From intentions to actions: A theory of planned behavior. In J. Kuhi, \& J. Beckman (Eds.), Action control: From cognition to behavior (pp. 11-39). New York: Springer, Heidelberg.

Arora, P. (2006). E-karaoke learning for gender empowerment in rural India. ICTDPaper\#106: University of California.

Chick, G. (2008). Leisure as a topic for cross-cultural research. Lecture given at National Dong Hwa University January 8, 2008.

Chuang, O. L. J., \& Hsu, Y. C. (2008). Girls Prefer to sing at KTV: A rational or reflective behavior?. The Journal of Travel Leisure, 14(3), 213-231.

Criss, E. (2008). The natural learning process. Music Educators Journal, 95(2), 42-46.

Dawe, K. (2005). "Power-geometry" in motion: Space, place and gender in the lyra music of Crete. Music, space and place: Popular music and cultural identity (pp. 55-65). Hants (UK): Ashgate.

Dickinson, K. (2005). "Believe”: Vocoders, digital female identity and camp. Music, space and place: Popular music and cultural identity (pp. 163-179). Hants (UK): Ashgate.

Drinker, H. S. (1967). Amateurs and music. Music Educators Journal, 54, 75-78.

EST KTV available song list. Retrieved from http://www.ikaraoke.kr/EST

EST KTV. Retrieved from http://estkara.com/?page_id=8

FANG, C. Y. (2009). A study of karaoke singing by mature adults in the Singaporean Chinese community (paper presented at the 3rd Redesigning Pedagogy International Conference, Singapore).

Folkestad, G. (2006). Formal and informal learning situations or practice vs formal and informal ways of learning. British Journal of Music Education, 23(2), 135-145.

Fun K-pop Internet KTV!! Free for your singing!!. Retrieved from http://sss501.pixnet.net/blog/post/32880352-好玩的韩国歌线 上ktv!!!免钱也能唱!!

Girl's Generation. Run Devil Run. Retrieved from http://www.youtube.com/watch?v=ACmznc4IJFA\&feature=related

Go, J. M. (2011). The possibility of the cultural and economic meaning for the new Korean wave of K-pop : Beyond the Appearance, Dance, Fashion and the Compound cultural production, forward to the building of the National Brand. Newspaper and Broadcast, 490, 48-52. Seoul: KPF(Korea Press Foundation).

Go, J. M., \& You, S. H. (2009). Korean wave, infinity of Asia and expand to world. Seoul: KOFIC.

Green, L. (2002). How popular musicians learn: A way ahead for music education. Aldershot: Ashgate.

Huang, W. C. (1994). The meanings of KTV for individual uses-The pleasure and the social uses analysis (Unpublished master's thesis). National Chiao Tung University, Hsin-zhu city, Taiwan.

Kelly, J. P. (1996). Leisure. Boston: Allyn and Bacon.

Kong-er lyrics. Retrieved from http://tw.knowledge.yahoo.com/question/question?qid=1511042802107

Kpop class. Retrieved from http://kpopclass.blogspot.tw/2011/10/davichi-love-my-love.html

Lee, I. M. (2012). “K-pop, New Genre” provide new space for K-pop in Youtube. Chosun daily. Retrieved from http://biz.chosun.com

Lilliestam, L. (1996). On playing by ear. Popular Music, 15(2), 195-216.

Lum, C. M. K. (1998). The Karaoke dilemma: On the interaction between collectivism and individualism in the karaoke space. In T. Mitsui, \& S. Hosokawa (Eds.), Karaoke around the world: Global technology, local singing (pp. 166-177). NY: Routledge.

Mayhew, E. (2004) Positioning the Producer: Gender divisions in creative labour and value. In S. Whitley, A. Bennett, \& S. Hawkins (Eds.). Music, space and place: Popular music and cultural identity (pp. 149-162). Aldershot: Ashgate Publishing Limited. 
Otake, A., \& Hosokawa, S. (1998). Karaoke in East Asia: Modernization, Japanization, or Asianization? In T. Mitsui, \& S. Hosokawa (Eds.), Karaoke around the world: Global technology, local singing (pp. 178-201). NY: Routledge.

QIU, J. Z. (2010). Leisure and mass media. Leisure sociology: Issues and challenges (pp. 222-236). Taipei : Yang-chih Book Com..

Roberts, K. (2010). Sociology of leisure. University of Liverpool.

SHINee. Hello. Retrieved from http://www.youtube.com/watch?v=vq_8AzohYgs\&feature=related

Small, C. (1998). Musicking: The meanngs of performing and listening (pp. 39-49). Middletown: Wesleyan University Press.

Super Junior. A-CHA. Retrieved from http://www.youtube.com/watch?v=5L8ZvKNJWzM\&feature=results_main\&playnext=1\&list=PL2FA08543BCC7DF2C

Super Junior. Mr. Simple. Retrieved from http://www.youtube.com/watch?v=M1S1C4hL84I\&feature=related

T-ARA. RolyPoly. Retrieved from http://www.youtube.com/watch?v=RV-Z0pGxZt0\&feature=related

Whiteley, S. (2000). Women and popular music: Sexuality, identity and subjectivity. The personal is political (pp. 44-50). NY: Routledge.

Won, Y. J. ([2009] 2010). Ch.7. feminism and popular culture. Rethinking the paradigm of popular culture (pp. 332-389). Seoul: Hannarae.

KTV (Executive two Korean KTV in Taipei). Retrieved from http://www.wretch.cc/blog/yaya984429/12092274

\section{Appendix}

Table 4-1

The List of Participants for Karaoke (Group A)

\begin{tabular}{|l|l|l|l|l|l|}
\hline No & Family Name & SEX & Year of Birth & Period of studying Korean/Language institute & Occupation \\
\hline A1 & Chen & F & 1980 & 3 years/Keep Korean class & Marketing \\
\hline A2 & Cheng & F & 1974 & More than 5 years/None & Sales \\
\hline A3 & Wu & F & 1983 & $\begin{array}{l}\text { More than 5 years/None } \\
\text { (Had been to Korea for studying Korean for 6 months) }\end{array}$ & Admin. \\
\hline A4 & Gao & F & 1977 & $\begin{array}{l}\text { More than 5 years/Keep Korean class } \\
\text { (Had been to Korea for studying Korean for 1 year) }\end{array}$ & Translator \\
\hline
\end{tabular}

Table 4-2

Run Down in KTV (Group A)

\begin{tabular}{|c|c|c|}
\hline $\begin{array}{l}\text { Time } \\
\text { (Genre / Sex) }\end{array}$ & $\begin{array}{l}\text { Title of Song } \\
\text { (Arritst or OST title) }\end{array}$ & $\begin{array}{l}\text { Conversations } \\
\text { (In Korean: Thick and underline) }\end{array}$ \\
\hline \multirow{2}{*}{$\begin{array}{l}\text { 0:00:00 0:03:05 } \\
\text { (Ballad/F) }\end{array}$} & \multirow{2}{*}{$\begin{array}{l}\text { \#1. Love, Oh love } \\
\text { (Davichi) }\end{array}$} & “Eon-ni (언니)!” \\
\hline & & [Sing together \& feedback ] “No, I don’t want to do” \\
\hline \multirow{2}{*}{$\begin{array}{l}\text { 0:03:30 0:07:38 } \\
\text { (Dance/F) }\end{array}$} & \multirow{2}{*}{$\begin{array}{l}\# 2 . \text { Ugly } \\
(2 \mathrm{NE1})\end{array}$} & “Let me find out a song, 'Su go hae sseo yo(辛苦你了)”” \\
\hline & & “You did good jod(做的好)” \\
\hline $\begin{array}{l}0: 7: 41 \sim 0: 11: 22 \\
(\text { Ballad/F) }\end{array}$ & $\begin{array}{l}\text { \#3. Men are all the same } \\
\text { (Rumble Fish) }\end{array}$ & $\begin{array}{l}\text { "I can’t sing this song" "Fine, let me sing alone" "You don't know Man? Men } \\
\text { are all same and not much special, haha" "Enough! Let singing this" }\end{array}$ \\
\hline $\begin{array}{l}0: 11: 30 \sim 0: 15: 52 \\
\text { (Ballad/M) }\end{array}$ & $\begin{array}{l}\text { \#4. Not me } \\
\text { (Pursuing) }\end{array}$ & “Hello?(여보세요?)” \\
\hline $\begin{array}{l}\text { 0:15:58 0:19:07 } \\
\text { (Ballad/F) }\end{array}$ & $\begin{array}{l}\# 5 \text {. I love you } \\
\text { (사랑 해 요) } \\
\text { (“Athena” OST on SBS) }\end{array}$ & $\begin{array}{l}\text { "Next song is ... I love you(사랑해요)”, “Too hard to sing” } \\
\text { [Sing together] "My love” "I love you(사랑해요)” }\end{array}$ \\
\hline $\begin{array}{l}\text { 0:19:13 0:23:02 } \\
\text { (Dance/F) }\end{array}$ & $\begin{array}{l}\# 6 . \text { You and I } \\
\text { (IU) }\end{array}$ & (Let’s together) “IU! IU!” “Wow, it’s too hard to sing, My god (아 , 씨!)” \\
\hline $\begin{array}{l}\text { 0:23:07 0:26:04 } \\
\text { (Ballad) }\end{array}$ & \#7. (Pursuing) & “Is this yours?” “Hellow?” "Yeh, That'mine” \\
\hline $\begin{array}{l}0: 26: 10 \sim 0: 29: 15 \\
(\text { Ballad/F) }\end{array}$ & $\begin{array}{l}\text { \#8. We meet again } \\
\text { (Kim, Yeonji (Siya)) }\end{array}$ & “Oh, It’s my song” “We have roll, lady. Don’t intercept song list.” \\
\hline $\begin{array}{l}\text { 0:29:23 0:33:39 } \\
\text { (Ballad/M) }\end{array}$ & $\begin{array}{l}\text { \#9. I've lost even my } \\
\text { friend (FT Island) }\end{array}$ & $\begin{array}{l}\text { “Next song is for me also” "Eon-ni (언니), Let’s sing together” } \\
\text { "Be quire!” }\end{array}$ \\
\hline 0:33:47 0:37:07 & \#10. We loving each & "We loving each other" "We ... did each other, Haha. It' so fun” "Ye, we did, \\
\hline
\end{tabular}




\begin{tabular}{|c|c|c|}
\hline (Rock Ballad/F) & $\begin{array}{l}\text { other } \\
\text { (Davichi \& T-ara) }\end{array}$ & did" “You did good job!” “The End!” \\
\hline $\begin{array}{l}0: 37: 12 \sim 0: 40: 41 \\
(\text { Ballad / F) }\end{array}$ & $\begin{array}{l}\text { \#11. I choose to love you } \\
\text { ("See the love2" OST ) }\end{array}$ & \\
\hline $\begin{array}{l}0: 40: 53 \sim 0: 44: 08 \\
\text { (Ballad) }\end{array}$ & $\begin{array}{l}\# 12 \text {. (Pursuing) } \\
\text { A kind of OST }\end{array}$ & \\
\hline $\begin{array}{l}0: 44: 20 \sim 0: 47: 30 \\
\text { (Dance/M) }\end{array}$ & $\begin{array}{l}\# 13 . \text { Dance with DJ } \\
\text { DOC (DJ DOC) }\end{array}$ & \\
\hline $\begin{array}{l}0: 47: 55 \sim 0: 51: 38 \\
\text { (Slow Beat song/F) }\end{array}$ & $\begin{array}{l}\# 14 . \text { One Person } \\
\text { (Chae yeon) }\end{array}$ & \\
\hline $\begin{array}{l}\text { 0:51:41 0:53:30 } \\
\text { (Ballad/F) }\end{array}$ & $\begin{array}{l}\text { \#15. I have a lover. } \\
\text { (Lee, Eunmi) }\end{array}$ & $\begin{array}{l}\text { "Do you have a boyfriend?” "No, why ask me that?" "Just asking” "Boyfriend? } \\
\text { Only disturbing me” "But I need one, haha!" "Oh, sheet! What a bad luck" }\end{array}$ \\
\hline $\begin{array}{l}0: 55: 35 \sim 0: 59: 55 \\
(\text { Ballad/F) }\end{array}$ & $\begin{array}{l}\text { \# 16. The man } \\
\text { (Secret garden OST) }\end{array}$ & \\
\hline $\begin{array}{l}\text { 1:00:02 1:02:52 } \\
\text { (Ballad/F) }\end{array}$ & $\begin{array}{l}\text { \#17. Loving you, today } \\
\text { (The Princess's Man } \\
\text { OST) }\end{array}$ & \\
\hline $\begin{array}{l}\text { 1:03:58 1:07:54 } \\
\text { (Dance/F) }\end{array}$ & $\begin{array}{l}\# 18 . \text { You and I (Park } \\
\text { Bom, a member of } \\
\text { 2NE1) }\end{array}$ & \\
\hline $\begin{array}{l}\text { 1:08:00 1:11:50 } \\
\text { (Ballad/F) }\end{array}$ & $\begin{array}{l}\text { \#19. Do you hear me? } \\
\text { (MBC Beethoven Virus } \\
\text { OST) }\end{array}$ & $\begin{array}{l}\text { "I’ve heard this song many times before" } \\
\text { "Here so much liquid smell in around this room” "Really?" }\end{array}$ \\
\hline $\begin{array}{l}\text { 1:11:56 1:15:20 } \\
\text { (Ballad) }\end{array}$ & $\begin{array}{l}\text { \#20. Bear doll } \\
\text { (Lin) }\end{array}$ & “I think enough, No need” "I like this song” \\
\hline $\begin{array}{l}\text { 1:15:28 1:19:46 } \\
\text { (Ballad) }\end{array}$ & $\begin{array}{l}\# 21 . \text { You are not clear to } \\
\text { know (KBS “Protect } \\
\text { boss” OST) }\end{array}$ & $\begin{array}{l}\text { “Let us sing together” “Oh, I don’t know this song” } \\
\text { “Hey, No next song here?” “Eonni, did you take a nap?” }\end{array}$ \\
\hline $\begin{array}{l}\text { 1:19:53 1:21:44 } \\
\text { (beat) }\end{array}$ & \begin{tabular}{|l}
$\# 22$. \\
(Pursuing)
\end{tabular} & $\begin{array}{l}\text { “Select for me Big bang’s 'Day by day'” } \\
\text { "Sorry, Not so good voice”. [Cut the song] }\end{array}$ \\
\hline $\begin{array}{l}\text { 1:21: 49 1:24:10 } \\
\text { (Dance/M) }\end{array}$ & $\begin{array}{l}\text { \#23. Day by day } \\
\text { (haruharu) } \\
\text { (Big Bang) }\end{array}$ & $\begin{array}{l}\text { [Cut the song] "Why? Why? What's wrong?” "Come on, re reservation!" "That } \\
\text { was too difficult to us” }\end{array}$ \\
\hline $\begin{array}{l}\text { 1:24:20 :1:28:52 } \\
\text { (Ballad) }\end{array}$ & $\begin{array}{l}\text { \#24.White love story } \\
\text { (MBC “Coffee prince” } \\
\text { OST) }\end{array}$ & "What are you doing?" \\
\hline $\begin{array}{l}\text { 1:28:58 1:32:56 } \\
\text { (Dance/?) }\end{array}$ & \begin{tabular}{|l}
$\# 25$. \\
(Pursuing)
\end{tabular} & "I’m really fine” "Too high” "Don’t angry, Come down” \\
\hline $\begin{array}{l}\text { 1:33:02 1:36:44 } \\
(\text { Ballad/M) }\end{array}$ & $\begin{array}{l}\text { \#26. 내가 이러지 } \\
\text { (Pursuing) }\end{array}$ & "Let me sing with you” \\
\hline $\begin{array}{l}\text { 1:36:51 1:39:54 } \\
\text { (Dance/F) }\end{array}$ & $\begin{array}{l}\text { \#27. I don’t care } \\
\text { (2NE1) }\end{array}$ & $\begin{array}{l}\text { “Oh! I don’t care” } \\
\text { [Sing together] “I don’t ca-ca-ca-re” }\end{array}$ \\
\hline $\begin{array}{l}\text { 1:40:00 1:44:25 } \\
\text { (Fast tempo/F) }\end{array}$ & $\begin{array}{l}\text { \#28. Lonely } \\
\text { (2NE1) }\end{array}$ & [Sing together] "Baby, I’m so lonely” \\
\hline $\begin{array}{l}\text { 1:44:30 1:48:18 } \\
\text { (Hip hop/M ) }\end{array}$ & $\begin{array}{l}\text { \#29. Living in the heart } \\
\text { (Untouchable) }\end{array}$ & “Time almost done. Ok, Last song”. \\
\hline
\end{tabular}

(Date: May 19, 2012 18:30-21:30/Place: EST KTV near the Zhongshan MRT station(中山站)).

Table 5-1

The List of Participants for Karaoke (Group B)

\begin{tabular}{|l|l|l|l|l|l|}
\hline No & Family Name & SEX & Year of Birth & Period of Studying Korean/Language institute & Occupation \\
\hline B1 & Hsie & F & 1976 & More than 5 years/Korean Institute in Taipei & Marketing \\
\hline B2 & Liao & F & 1985 & More than 5 years/Korean Institute in Taipei & Sales \\
\hline B3 & Tsai & F & 1980 & More than 5 years/Korean Institute in Taipei & Admin \\
\hline B4 & Lee & F & 1982 & More than 3 years/Korean Institute in Taipei & Officer \\
\hline B5 & Chen & F & 1986 & More than 5 years/None & Translator \\
\hline
\end{tabular}


Table 5-2

Run Down in KTV (Group B)

\begin{tabular}{|c|c|c|}
\hline $\begin{array}{l}\text { Time } \\
\text { (Genre/Sex) }\end{array}$ & $\begin{array}{l}\text { Title of Song } \\
\text { (Arritst or OST title) }\end{array}$ & $\begin{array}{l}\text { Conversations } \\
\text { (Korean: Thick and underline) }\end{array}$ \\
\hline 0:00:00 0:02:30 & (Talk) & $\begin{array}{l}\text { [Facility and arrange Drinks]/“"This remote control not pretty much workable” } \\
\text { “Oh, You got hair cut. Look great”/[Select songs] "I’d like to sing 2AM’s new } \\
\text { song” }\end{array}$ \\
\hline 0:02:31 0:06:16 & $\begin{array}{l}\text { \#1. I wonder if you hurt } \\
\text { like me (2AM) }\end{array}$ & $\begin{array}{l}\text { Photos/Volume control/Select songs/“What should I sing? Anybody selected } \\
\text { songs?” }\end{array}$ \\
\hline 0:06:11 0:06:40 & (Talk) & “Here is not enough new songs, No new song list in June” \\
\hline $\begin{array}{l}0: 06: 41 \sim 0: 11: 19 \\
\text { (Fast Ballad) }\end{array}$ & $\begin{array}{l}\text { \#2. Can’t forgive you } \\
\text { (SBS ‘Wife's lure' OST) }\end{array}$ & $\begin{array}{l}\text { “'Ok, Here we go”/“'Oh, Someone selected Baek jiyoung’s song?” "Yeh, I like } \\
\text { that song”/“Hurt!” "Hurt? Oh, You really feel hurt your throat. I misunderstood } \\
\text { you wanna sing ‘Hurt’ for next song” }\end{array}$ \\
\hline $\begin{array}{l}\text { 0:11:27 0:14:52 } \\
\text { (Dance) }\end{array}$ & $\begin{array}{l}\text { \#3. Russian Roulette } \\
\text { (Spica) }\end{array}$ & $\begin{array}{l}\text { "I like this song’s MV”/[Take pictures]/“Who singing this Song?” "Who is } \\
\text { Spica? I’ve never heard before” }\end{array}$ \\
\hline $\begin{array}{l}\text { 0:15:06 0:18:58 } \\
(\text { Ballad/F) }\end{array}$ & $\begin{array}{l}\text { \#4. Loving you, today } \\
\text { (KBS “The Princes” Man’ } \\
\text { OST) }\end{array}$ & $\begin{array}{l}\text { “What is Next Song? Oh, I Know this song.<The Princes’ Man>OST, right?” } \\
\text { "I'm not seen the drama yet.” "I've seen that already. But I’m not clear lyric” "I } \\
\text { can sing the Original song, but I can’t sing the cover version coz the part of } \\
\text { rap”/“Who can sing IU’s new song?” "Nope, I can’t. C: Me, too” }\end{array}$ \\
\hline $\begin{array}{l}\text { 0:18:59 0:19:15 } \\
\text { (Ballad) }\end{array}$ & (talk) & $\begin{array}{l}\text { "Wow, My dear! You're really something. You can sing this song only take } \\
\text { watch the drama? I just listen the OST, but didn’t repeat the song” }\end{array}$ \\
\hline $\begin{array}{l}\text { 0:19:17 0:22:35 } \\
\text { (Ballad) }\end{array}$ & $\begin{array}{l}\text { \#5. A word what I want to } \\
\text { say ( 《Rooftop prince》 } \\
\text { OST) }\end{array}$ & $\begin{array}{l}\text { "Next is Roodtop... ”/“Let me sing this song!” "B: Oh! Go ahead”/“I didn’t } \\
\text { watch this drama”"Really? What make you so busy?”/“Let’ s arrange this song. } \\
\text { I believe everybody familiar this song. Sing together” }\end{array}$ \\
\hline $\begin{array}{l}0: 22: 48 \sim 0: 26: 28 \\
(\text { Ballad/F) }\end{array}$ & $\begin{array}{l}\text { \#6. Missing you just like } \\
\text { crazy (MBC “The King } 2 \\
\text { heart” OST) }\end{array}$ & $\begin{array}{l}\text { "I’ve watched this Drama all” "I’m not yet”/“ Find me 'Like a stranger' and ... } \\
\text { 'Confession”” }\end{array}$ \\
\hline $\begin{array}{l}0: 26: 32 \sim 0: 30: 25 \\
\text { (Ballad/F) }\end{array}$ & \begin{tabular}{|l} 
\#7. Do you hear me? (MBC \\
Beethoven Virus OST)
\end{tabular} & $\begin{array}{l}\text { “"What song?” “Do you hear me. It means ‘do you hear me?’ in Chinese” “Oh, } \\
\text { Singer is SNSD’s leader, right?” }\end{array}$ \\
\hline $\begin{array}{l}0: 30: 35 \sim 0: 34: 28 \\
(\text { Ballad/M) }\end{array}$ & $\begin{array}{l}\text { \#8. More Closer } \\
\text { (SBS ‘The brain’ OST) }\end{array}$ & $\begin{array}{l}\text { “That’s too much new song. Oh, I like this song.”/ } \\
\text { “Why don’t someone sing with me?” "Nice voice. Obba, Obba!” }\end{array}$ \\
\hline $\begin{array}{l}\text { 0:34:37 0:39:02 } \\
(\text { Ballad/F) }\end{array}$ & $\begin{array}{l}\text { \#9. Day by day } \\
\text { (As One) }\end{array}$ & $\begin{array}{l}\text { “'Ok, Who wanna sing the new JYJ Jun-su’s song?”/“That’s a good sound } \\
\text { song”/“As one is in Korean or in English? I know another song” }\end{array}$ \\
\hline $\begin{array}{l}\text { 0:39:10 0:43:05 } \\
\text { (Dance, Cute/F) }\end{array}$ & $\begin{array}{l}\# 10 . \text { You and I } \\
\text { (IU) }\end{array}$ & $\begin{array}{l}\text { "IU song? Everyone can singing this song”/“"Ok, Select a song, Coffee prince } \\
\text { OST, for me’ }\end{array}$ \\
\hline $\begin{array}{l}0: 43: 20 \sim 0: 49: 27 \\
(\text { Ballad/M) }\end{array}$ & $\begin{array}{l}\text { \#11. The sketch of Memory } \\
\text { (Korean film OST) }\end{array}$ & $\begin{array}{l}\text { “Let me sing the song of Lee Eun-mi” "Lee Eun Mi version’s song ? I have a } \\
\text { lover?”/“You’ve seen the film, right?” "No, not yet” "Wow, How did you sing } \\
\text { this song?”/“No 'To you' lyric in this version song. Maybe this is a different } \\
\text { version that I have lyrics version.” }\end{array}$ \\
\hline $\begin{array}{l}0: 49: 35 \sim 0: 54: 05 \\
(\text { Ballad/F) }\end{array}$ & $\begin{array}{l}\text { \#12. I want to dream with } \\
\text { you forever (MBC Pasta } \\
\text { OST (SNSD)) }\end{array}$ & $\begin{array}{l}\text { "Ok. This song is for all of us.”/“"I believe’, This song is a famous one. Ye, It is } \\
\text { an anther OST” }\end{array}$ \\
\hline $\begin{array}{l}0: 54: 09 \sim 0: 57: 45 \\
\text { (Dance/F) }\end{array}$ & $\begin{array}{l}\# 13 . \text { I don’t know } \\
\text { (A pink) }\end{array}$ & $\begin{array}{l}\text { “Let’s order a rock song!?”/“You really great. How do you remember the lyric } \\
\text { only one listing” }\end{array}$ \\
\hline $\begin{array}{l}0: 57: 52 \sim 1: 01: 46 \\
\text { (Rock Ballad/M) }\end{array}$ & $\begin{array}{l}\text { \#14. For you } \\
(\text { Im Jaebeom) }\end{array}$ & \\
\hline $\begin{array}{l}\text { 1:01:50 1:06:37 } \\
\text { (Rock Ballad/M) }\end{array}$ & $\begin{array}{l}\text { \#15. Confession } \\
\text { (Im Jaebeom) }\end{array}$ & $\begin{array}{l}\text { “Who wanna sing with me? I can sing the first lyrics” "It’s not a new song?” } \\
\text { "Lee Seung-ji want to come Taiwan. Let me see his song”/“ } \sim \text { Forgive Me”: I } \\
\text { can’t forgive you(In Korean”/“Who know } \leq \text { Miss you> this song?” }\end{array}$ \\
\hline $\begin{array}{l}\text { 1:06:43 1:11:16 } \\
\text { (Ballad/M) }\end{array}$ & $\begin{array}{l}\text { \#16. Love } \\
(\text { Im Jaebeom) }\end{array}$ & “Cause love (Sarang)? Who’ song?” “Singer is $\underline{\operatorname{Im}, \text { Jaebeom” }}$ \\
\hline $\begin{array}{l}\text { 1:11:22 1:15:10 } \\
\text { (Ballad) }\end{array}$ & $\begin{array}{l}\text { \#17.Like Star } \\
\text { (Taeyeon \& The One) }\end{array}$ & “Two part separated song, Taeyeon and a Man voice”/“Oh, this part is for male” \\
\hline 1:15:11 1:15:22 & (talk) & “Would you check a song, but that is a kind of old K-pop” \\
\hline $\begin{array}{l}: 15: 23 \sim 1: 18: 45 \\
\text { (Fast Ballad/F) }\end{array}$ & $\begin{array}{l}\text { \#18. We were in love } \\
\text { (Davichi \& T-ara) }\end{array}$ & $\begin{array}{l}\text { "You have to rap, but I didn’t practice rap” “Then just skip the rap”/[Clap!] } \\
\text { "Yah, Come on! One more rap song!” }\end{array}$ \\
\hline 1:18:50 1:22:05 & \#19. Obba, Here (Super & “Lee, you Solo!” \\
\hline
\end{tabular}




\begin{tabular}{|c|c|c|}
\hline (Dance/M) & \begin{tabular}{|l} 
Junior Donghae \& \\
Eunhyeok)
\end{tabular} & [Sing together] Corus: "Obba! (오빠!) Obba! (오빠)”, “Wow! (아싸!)” \\
\hline $\begin{array}{l}1: 22: 10 \sim 1: 25: 40 \\
(\text { Ballad/M) }\end{array}$ & $\begin{array}{l}\text { \#20. You, my dear (MBC } \\
\text { "the lunar eclipsed sun" } \\
\text { OST) }\end{array}$ & \\
\hline $\begin{array}{l}1: 25: 45 \sim 1: 29: 35 \\
\text { (Rock Ballad) }\end{array}$ & $\begin{array}{l}\text { \#21. You're so beautiful } \\
\text { (JYJ Xia Jun-su) }\end{array}$ & "You are so beautiful !” "I know that song” \\
\hline 1:29:36 1:29:41 & (talk) & $\begin{array}{l}\text { "I can't remember the title of good song. Do you know that?" "Saranghae! } \\
\text { Saranghae(loving you? loving you?)?" }\end{array}$ \\
\hline $\begin{array}{l}\text { 1:29:42 1:33:22 } \\
\text { (Ballad/M) }\end{array}$ & $\begin{array}{l}\text { \#22. Too love (KBS } \\
\text { "Seonggungwan Scandal” } \\
\text { OST) }\end{array}$ & "Wow, I like this song. Nice melody" \\
\hline $\begin{array}{l}1: 33: 30 \sim 1: 36: 48 \\
\text { (Fast tempo/M) }\end{array}$ & $\begin{array}{l}\text { \#23. Find out (KBS } \\
\text { "Seonggungwan Scandal” } \\
\text { OST) }\end{array}$ & \\
\hline $\begin{array}{l}1: 36: 52 \sim 1: 41: 25 \\
(\text { Ballad/F) }\end{array}$ & $\begin{array}{l}\text { \#24. White love story } \\
\text { (MBC “Coffee prince” } \\
\text { OST) }\end{array}$ & $\begin{array}{l}\text { "Have you ever sing this song before?” } \\
\text { “Next song is Shinee’s? Right? Who’s next turn?” }\end{array}$ \\
\hline $\begin{array}{l}\text { 1:41:32 1:45:15 } \\
(\text { Jazz/M) }\end{array}$ & $\begin{array}{l}\text { \#25. Ocean travel (MBC } \\
\text { "Coffee prince” OST) }\end{array}$ & $\begin{array}{l}\text { "Wow, what a very slow song”. } \\
\text { "Select for me <I do, I do > "Lots of people like him" } \\
\end{array}$ \\
\hline $\begin{array}{l}\text { 1:45:25 1:49:20 } \\
\text { (Ballad) }\end{array}$ & $\begin{array}{l}\text { \#26. I have a lover } \\
\text { (Lee, Eun-mi) }\end{array}$ & $\begin{array}{l}\text { "Do you know < The song that only you could listen (너만 들을 수 있는 } \\
\text { 노래)>?” "I wanna sing the "Man better than flower (花样男子)" OST” }\end{array}$ \\
\hline $\begin{array}{l}\text { 1:49:28 1:53:12 } \\
\text { (Ballad) }\end{array}$ & \begin{tabular}{|l} 
\#27. I believe \\
(My Sassy Girl OST)
\end{tabular} & $\begin{array}{l}\text { "Ha, Everybody know this song" "Why don’t you sing in Chinese a part" } \\
\text { [Sing together] Korean version and Chinese version "It’s fun" }\end{array}$ \\
\hline $\begin{array}{l}1: 54: 18 \sim 1: 58: 32 \\
(\mathrm{R} \& \mathrm{~B} / \mathrm{M})\end{array}$ & \#28. Propose ( No-eul ) & $\begin{array}{l}\text { "What is song?" "You must heard before, I believe it familiar to you, absolutely" } \\
\text { "But No. It’s first heard”/Singer No-eul, They are out from the Idol contest TV } \\
\text { program. And this is a one of popular wedding song in Korea. I’ve heard the } \\
\text { song in the real show program too.” }\end{array}$ \\
\hline $\begin{array}{l}\text { 1:58:38 2:02:10 } \\
\text { (Disco Dance) }\end{array}$ & $\begin{array}{l}\text { \#29. Lovey dovey } \\
\text { (T-ara) }\end{array}$ & $\begin{array}{l}\text { "Ye! Come on!” } \\
\text { [Sing together] Lovey dovey! Lovey dovey! Woo ! } \\
\end{array}$ \\
\hline $\begin{array}{l}\text { 2:02:16 2:05:48 } \\
\text { (Disco Dance) }\end{array}$ & $\begin{array}{l}\text { \#30. Roly Poly } \\
\text { (T-ara) }\end{array}$ & [Sing together] “ don’t know (몰라)! don’t know (몰라)” \\
\hline $\begin{array}{l}\text { 2:05:15 2:09:44 } \\
(\text { Ballad/F) }\end{array}$ & $\begin{array}{l}\text { \#31. Maybe (KBS “Scent } \\
\text { of Summer” OST) }\end{array}$ & $\begin{array}{l}\text { “Oh, Scent of Summer OST” “I’ve seen this drama” "But I’m not” } \\
\text { “And there is Chinese version too” }\end{array}$ \\
\hline $\begin{array}{l}\text { 2:09:52 2:14:55 } \\
\text { (fast song) }\end{array}$ & $\begin{array}{l}\text { \#32. Everyday } \\
\text { (J-pop/AKB48) }\end{array}$ & $\begin{array}{l}\text { "This new version or original?” “This is original version” } \\
\text { [Sing together] Every Every day! “AKB48, then how they separate sing each } \\
\text { other?” }\end{array}$ \\
\hline $\begin{array}{l}\text { 2:15:02 2:18:59 } \\
\text { (Fast tempo) }\end{array}$ & \begin{tabular}{|l|} 
\#33. Love light \\
(CNblue)
\end{tabular} & “Actually, I can sing the front part” \\
\hline $\begin{array}{l}\text { 2:19:05 2:19:29 } \\
\text { (Rock ballad/M) }\end{array}$ & $\begin{array}{l}\# 34 \text {. I need you (K.Will) } \\
\text { [Not for singing] }\end{array}$ & $\begin{array}{l}\text { "Who's song?” "Chue woo hyeok" "Oh ! I see. But I can sing his another song, } \\
\text { not this one”/“OK, enough! let me cut this song now" }\end{array}$ \\
\hline $\begin{array}{l}\text { 2:19:32 2:23:26 } \\
(\text { Ballad/F) }\end{array}$ & $\begin{array}{l}\text { \#35. The song that only I } \\
\text { can sing (Bada) }\end{array}$ & $\begin{array}{l}\text { "I don’t remember this song. I've just seen only story 1. of the soap opera” } \\
\text { "Do you know "Don’t say Ah-nyeong”?” "Is this OST?/No, This song made by } \\
\text { Gerry who is a guest in MBC 'the infinity challenge') }\end{array}$ \\
\hline $\begin{array}{l}2: 23: 31 \sim 2: 24: 15 \\
\text { (Rock Ballad/M) }\end{array}$ & $\begin{array}{l}\text { \#36. Severely } \\
\text { (FT Island) }\end{array}$ & $\begin{array}{l}\text { “'Oh! FTIsland” “Who reservayed”/“Ok, No one wanna sing this, then let me } \\
\text { cut” }\end{array}$ \\
\hline $\begin{array}{l}\text { 2:24:20 2:26:07 } \\
\text { (Dance/M) }\end{array}$ & $\begin{array}{l}\# 37 . \text { Crazy } \\
\text { (Teen top) }\end{array}$ & $\begin{array}{l}\text { [Sing together] I need you Baby Baby Baby, I want you baby baby baby } \\
\text { "What a fast song” “'Ok. Then I’d like sing 'Don't forget”” “Baek ji young’s } \\
\text { song?” }\end{array}$ \\
\hline $\begin{array}{l}\text { 2:26:11 2:30:32 } \\
\text { (Ballad / M) }\end{array}$ & $\begin{array}{l}\text { \#38. I hope it would be that } \\
\text { way now (Jo Yongpil ) }\end{array}$ & $\begin{array}{l}\text { “I know this song. It looks like an old song. So who’s version”/“Is this for } \\
\text { Women song?” "No, Singer is male”/“I’ve heard this song another TV program, } \\
\text { the singer was a woman” }\end{array}$ \\
\hline $\begin{array}{l}\text { 2:30:38 2:35:05 } \\
\text { (Ballad/M) }\end{array}$ & $\begin{array}{l}\text { \#39. Nameless Memory } \\
\text { (SS501's Heo Y.S.) }\end{array}$ & $\begin{array}{l}\text { "The song is showed up on the TV program, "One night two days" } \\
\text { "Oh! Woori, Woori. That means us in Chinese" }\end{array}$ \\
\hline $\begin{array}{l}\text { 2:35:11 2:38:46 } \\
\text { (Fast song/F) }\end{array}$ & $\begin{array}{l}\text { \#40. Don’t say good bye } \\
\text { (Davichi) }\end{array}$ & \\
\hline $\begin{array}{l}2: 38: 54 \sim 2: 42: 22 \\
\text { (Dance Ballad/F) }\end{array}$ & $\begin{array}{l}\text { \#41. Love, Oh love } \\
\text { (Davichi) }\end{array}$ & \\
\hline 2:42:30 2:46:35 & \#42. Rain and You (Korean & “Next is a kind of OST, right?" "I’ve heard this song” "So many people sang this \\
\hline
\end{tabular}




\begin{tabular}{|c|c|c|}
\hline (Rock Ballad/M) & film 'Radio stat' OST) & $\begin{array}{l}\text { song before. I know it is very famous song" "Yeh, I've heard several cover } \\
\text { version" }\end{array}$ \\
\hline $\begin{array}{l}\text { 2:46:43 2:50:48 } \\
\text { (Ballad/F) }\end{array}$ & $\begin{array}{l}\text { \#43. The man } \\
\text { (KBS “Secret Garden” } \\
\text { OST) }\end{array}$ & “Nobody don't know this song. Let’s together sing” \\
\hline $\begin{array}{l}\text { 2:50:55 2:54:48 } \\
\text { (Dance/F) }\end{array}$ & $\begin{array}{l}\text { \#44. Bring the boys out } \\
\text { (SNSD) }\end{array}$ & \\
\hline $\begin{array}{l}\text { 2:54:53 2:58:05 } \\
\text { (Ballad/F) }\end{array}$ & $\begin{array}{l}\text { \#45. I love you(사랑 해요) } \\
\text { (SBS “Athena” OST) }\end{array}$ & “Taeyeon's song”/“Your best songs are slow tempo song, like this song”. \\
\hline $\begin{array}{l}\text { 2:58:18 3:02:40 } \\
(\text { Ballad/F) }\end{array}$ & $\begin{array}{l}\text { \#46. Father } \\
\text { (In-su-ni) }\end{array}$ & $\begin{array}{l}\text { “This song is really touchable song” “A-Beo-Ji (my father) !" "I've seen the } \\
\text { film(Aftershock 唐山大地震) only 30mins but it did touch my heart” }\end{array}$ \\
\hline $\begin{array}{l}\text { 3:02:47 3:06:20 } \\
\text { (Ballad/F) }\end{array}$ & \begin{tabular}{|l|} 
\#47. Can’t love \\
(Seo In-young)
\end{tabular} & $\begin{array}{l}\text { "Sing together”/“Why I've never heard this song? So who is the artist?” "Her } \\
\text { name is Seo In-young”/“Maybe the last song? Right?” }\end{array}$ \\
\hline
\end{tabular}

(Date : June 30, 2012 15:30-18:30/Place: EST KTV near the Zhong-shan MRT station (中山站)) 